University of Nebraska - Lincoln

DigitalCommons@University of Nebraska - Lincoln

Publications, Agencies and Staff of the U.S.

Department of Commerce

U.S. Department of Commerce

2010

\title{
Meridional patterns in the deep scattering layers and top predator distribution in the central equatorial Pacific
}

Elliott L. Hazen

NOAA SWFSC Pacific Fisheries Environmental Lab, elliott.hazen@noaa.gov

David W. Johnston

Duke University Marine Lab, david.johnston@duke.edu

Follow this and additional works at: https://digitalcommons.unl.edu/usdeptcommercepub

Part of the Environmental Sciences Commons

Hazen, Elliott L. and Johnston, David W., "Meridional patterns in the deep scattering layers and top predator distribution in the central equatorial Pacific" (2010). Publications, Agencies and Staff of the U.S. Department of Commerce. 275.

https://digitalcommons.unl.edu/usdeptcommercepub/275

This Article is brought to you for free and open access by the U.S. Department of Commerce at DigitalCommons@University of Nebraska - Lincoln. It has been accepted for inclusion in Publications, Agencies and Staff of the U.S. Department of Commerce by an authorized administrator of DigitalCommons@University of Nebraska - Lincoln. 


\section{SHORT COMMUNICATION \\ Meridional patterns in the deep scattering layers and top predator distribution in the central equatorial Pacific}

\author{
ELLIOTT L. HAZEN ${ }^{1,2, *}$ AND DAVID W. \\ JOHNSTON $^{1}$ \\ ${ }^{1}$ Division of Marine Science and Conservation, Nicholas School \\ of the Environment, Duke University Marine Lab, 135 Duke \\ Marine Lab Rd., Beaufort, NC 28516, USA \\ ${ }^{2}$ NOAA SWFSC Pacific Fisheries Environmental Lab, 1352 \\ Lighthouse Ave., Pacific Grove, CA 93950, USA
}

\begin{abstract}
The deep scattering layers (DSL) in the central equatorial Pacific form an important prey resource in a relatively oligotrophic habitat. In March of 2006, we used a calibrated $38-\mathrm{kHz}$ SIMRAD EK60 scientific sonar to assess the spatial distribution of the deep scattering layer relative to broad-scale oceanographic features and fine-scale physical and biological measurements. We conducted a single continuous transect from approximately $10^{\circ} \mathrm{S}$ to $20^{\circ} \mathrm{N}$ at $170^{\circ} \mathrm{W}$ while measuring acoustic backscatter, current velocity and direction, temperature, salinity, oxygen, and fluorescence with depth, coincident with marine mammal occurrence. These data were combined with remotely sensed sea surface height, chlorophyll, and sea surface temperature data to examine patterns in DSL distribution. To analyze DSL density with depth, acoustic backscatter was binned into surface $(<200 \mathrm{~m})$, mid $(200-550 \mathrm{~m})$ and deep $(550-1000 \mathrm{~m})$ layers. Backscatter was highly correlated with chlorophyll-a and low sea surface height anomalies and was greatest near the equator. We found high diel variability in DSL depth and scattering intensity between the mid and surface layers as well as a shallowing of the deep layer moving northward across the equator. Marine mammal sightings consisted primarily of odontocetes with their distribution coincident with higher acoustic densities of their forage base. Shifts in DSL distribution and scattering intensity are an important
\end{abstract}

*Correspondence. e-mail: elliott.hazen@noaa.gov

Received 21 October 2009

Revised version accepted 27 June 2010 component towards understanding the behavior and distribution of highly migratory predator species.

Key words: acoustics, deep scattering layer, equatorial Pacific, marine mammal, oceanography

\section{INTRODUCTION}

Deep scattering layers (DSL) were first described in 1948 (Barham, 1948) and have since been observed at various depths and in multiple oceans around the world (Tont, 1976). In the central equatorial Pacific, the DSL is characterized primarily by lantern fish (Myctophids), squid, shrimp, and gelatinous plankton (Clarke, 1973; Tont, 1976; Domokos et al., 2007). Layers of the DSL exhibit varied vertical migrations with behaviors ranging from migrating to the surface at night from aphotic waters to deep static layers that remain at depth exhibiting no diel pattern (Tont, 1976). The DSLs that exhibit diel vertical migration are optimizing foraging while also limiting predation risk (Gliwicz, 1986; Longhurst, 2006). Organisms in the DSL form an important component of the food web linking zooplankton to top predators (Roger and Grandperrin, 1976). The strength and location of the DSL is an important factor in predicting top predator distribution (Dagorn et al., 2000; Ballance et al., 2006), and consequently fishery productivity (Domokos et al., 2007). Ultimately, a better understanding of the DSL can inform science and management of top predators (e.g., Jaquet and Whitehead, 1996; Bertrand et al., 2002).

We surveyed the physical and biological oceanography, acoustic backscatter, and marine mammals on a single transect from $10^{\circ} \mathrm{S}$ to $20^{\circ} \mathrm{N}$ latitude at a longitude of approximately $170^{\circ} \mathrm{W}$. Data from conductivity/temperature/depth (CTD) sensors, acoustic echosounders, acoustic Doppler current profilers (ADCPs), and satellite imagery were used to map physical and biological gradients and to examine their relation to scattering intensity, distribution of DSL, and potential predators. Our goal was to further examine how DSL scattering intensity varied with previously described water masses and currents in the central equatorial Pacific. 


\section{METHODS}

\section{Data collection}

We collected concurrent measures of backscatter of the DSL and physical variables aboard the R/V Oscar Elton Sette from 6 to 29 March 2006 in the central equatorial Pacific. The spatial extent of the cruise was from $10^{\circ} \mathrm{S}$ to $20^{\circ} \mathrm{N}$ and from $174.8^{\circ} \mathrm{W}$ to $162.2^{\circ} \mathrm{W}$, departing from American Samoa and arriving in Honolulu, HI (Fig. 1). Hull-mounted and calibrated SIMRAD EK60s operating at 38 and $120 \mathrm{kHz}$ recorded backscatter at an average frequency of five pings per second with pulse widths of 1024 and $512 \mathrm{~ms}$ and beam widths of $12^{\circ}$ and $7^{\circ}$, respectively. Current direction and velocity were measured using a Teledyne $\mathrm{RD}$ Instruments ADCP (Teledyne RD Instruments, 14020 Stowe Drive, Poway, CA 92064, USA) operating at $75 \mathrm{kHz}$. Temperature $\left({ }^{\circ} \mathrm{C}\right)$, salinity, dissolved oxygen $\left(\mathrm{mg} \mathrm{L}^{-1}\right)$, and fluorescence profiles were measured using a Seabird SBE 19 CTD (Sea-Bird Electronics, Inc., 13431 NE 20th Street, Bellevue, WA 98005, USA) deployed approximately every

Figure 1. Cruise track with total water column backscatter at $38 \mathrm{kHz}$ in $25 \times 25 \mathrm{~km}$ grid cells. Negative sea surface height anomaly ( $\mathrm{SSH}$ ) in dark gray with positive $\mathrm{SSH}$ values in light gray. Each marine mammal sighting is shown in white.

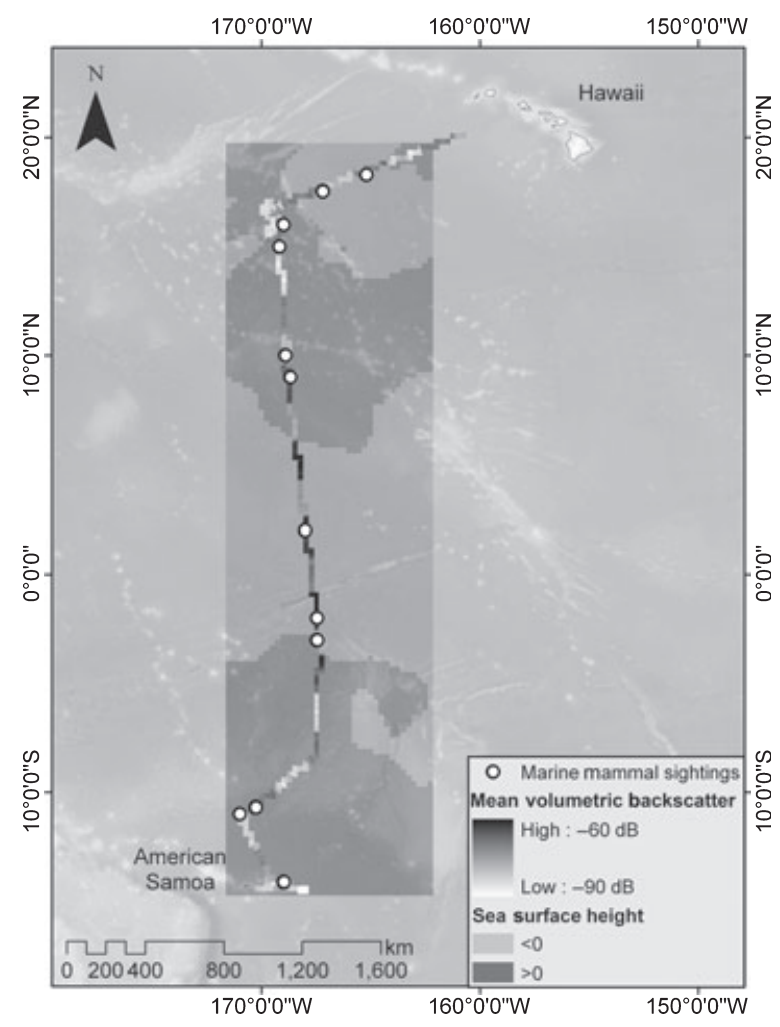

$25 \mathrm{~km}$ with temperature profiles also measured using expendable bathythermographs (XBTs) to $500 \mathrm{~m}$ depth every $4 \mathrm{~km}$ during daylight hours (6.00$15.00 \mathrm{~h}$ ). Visual surveys for marine mammals were conducted using standard line transect methods (e.g., Buckland 1993) during daylight hours. However, because this was a single transect, we are unable to completely separate the temporal and spatial patterns in our analyses.

Satellite imagery was used to examine sea surface temperature (SST), sea surface height anomaly and deviance (SSHA and SSH. Dev, respectively), and ocean color in relation to the transect. SST $\left({ }^{\circ} \mathrm{C}\right)$ was blended from AVHRR sensors, the MODIS Aqua and Terra sensors, the GOES Imager, and the AMSR-E sensor into an 8-day product and pixels with cloud cover or bad data were excluded (Powell et al., 2008). $\mathrm{SSH}$ anomaly grids (from a 7-yr mean ellipsoid, $\mathrm{cm}$ ) were averaged from AVISO satellite data into 7-day windows at $30 \mathrm{~km}$ resolution. Sea surface chlorophyll$a$ density $\left(\mathrm{mg} \mathrm{m}^{-3}\right)$ was from SeaWiFS at $27-\mathrm{km}$ resolution and compiled into an 8-day surface. Each product was sampled by nearest survey day and location to optimize temporal accuracy. When cloud cover obscured a sampling cell, the mean of the previous and following period was used as a proxy.

\section{Analysis}

Acoustic data were processed using Myriax's ECHOVIEW(v3.5, GPO Box 1387, Hobart, Tasmania 7001, Australia) into $10-\mathrm{m}$ vertical by $0.25-\mathrm{km}$ horizontal bins using a threshold of $-90 \mathrm{~dB}$ and a $5-\mathrm{m}$ surface exclusion from the ship's hull. Only $38 \mathrm{kHz}$ data were used in these analyses because DSL depths were often beyond the operational range of $120 \mathrm{kHz}$ during the survey $(200 \mathrm{~m})$. We used a noise removal algorithm that analyzed the vertical structure of each ping and removed those with a backscatter threshold $>95 \%$ of the water column to eliminate pings from electrical or mechanical interference. Although species composition or numerical abundance cannot be assessed from single frequency acoustic data alone, relative analyses of depth and distribution of scattering layer organisms can be investigated for their relationship with top predator behavior (Benoit-Bird and Au 2003).

CTD data were analyzed using SBE Data Processing and ADCP data were analyzed in MATLAB (MathWorks' MATLAB, 3 Apple Hill Drive, Natick, MA 01760-2098, USA) using CODAS to calculate meridionial and zonal velocities (Firing et al., 1995). Using a $20-\mathrm{m}$ vertical analysis window, the depths of the thermocline and oxycline were calculated using two methods; (i) by selecting the depth with the 
Table 1. GAM results for non-linear relationships of backscatter with: latitude, thermocline depth $(1=$ maximum change, 2 = maximum variance), oxycline $(1=$ maximum change, 2 = maximum variance $)$, total water column fluorescence, depth of maximum fluorescence, SSHA, SSH deviance (SSH.SD), SST (night), surface chlorophyll $\left(\mathrm{mg} \mathrm{m}^{-3}\right)$, and time.

\begin{tabular}{|c|c|c|c|c|c|c|c|c|c|}
\hline & \multirow[b]{2}{*}{$\mathrm{df}$} & \multicolumn{2}{|c|}{ Surface backscatter } & \multicolumn{2}{|c|}{ Mid backscatter } & \multicolumn{2}{|c|}{ Deep backscatter } & \multicolumn{2}{|c|}{ Total backscatter } \\
\hline & & $F$ value & $P(F)$ & $F$ value & $P(F)$ & $F$ value & $P(F)$ & $F$ value & $P(F)$ \\
\hline s(Lat) & 3 & 0.964 & 0.411 & 1.283 & 0.282 & 20.548 & 0.000 & 4.551 & 0.004 \\
\hline s(THERMO.1) & 3 & 2.980 & 0.033 & 1.985 & 0.118 & 4.448 & 0.005 & 4.735 & 0.003 \\
\hline s(THERMO.2) & 3 & 1.157 & 0.327 & 3.440 & 0.018 & 4.267 & 0.006 & 0.880 & 0.453 \\
\hline $\mathrm{s}(\mathrm{OXY} .1)$ & 3 & 5.633 & 0.001 & 2.637 & 0.051 & 2.958 & 0.034 & 7.720 & 0.000 \\
\hline s(OXY.2) & 3 & 1.941 & 0.125 & 0.525 & 0.665 & 1.718 & 0.165 & 2.331 & 0.076 \\
\hline s(FL.TOTAL) & 3 & 1.707 & 0.167 & 1.969 & 0.120 & 12.711 & 0.000 & 2.839 & 0.039 \\
\hline s(FluorDep) & 3 & 3.088 & 0.028 & 4.806 & 0.003 & 2.158 & 0.094 & 4.819 & 0.003 \\
\hline $\mathrm{s}(\mathrm{SSHA})$ & 3 & 0.714 & 0.545 & 3.982 & 0.009 & 1.982 & 0.118 & 2.122 & 0.099 \\
\hline s(SSH.dev) & 3 & 0.676 & 0.568 & 2.841 & 0.039 & 1.247 & 0.294 & 1.152 & 0.330 \\
\hline s(SST) & 3 & 1.818 & 0.145 & 5.045 & 0.002 & 4.601 & 0.004 & 3.131 & 0.027 \\
\hline s(CHLa) & 3 & 0.798 & 0.497 & 3.144 & 0.026 & 1.084 & 0.357 & 2.514 & 0.060 \\
\hline s(TIME) & 3 & 154.435 & 0.000 & 11.654 & 0.000 & 24.433 & 0.000 & 78.682 & 0.000 \\
\hline
\end{tabular}

Significant $P$-values $(<0.05)$ are shown in bold.

greatest absolute change within the window $(\Delta)$ and (ii) by selecting the depth with the greatest variance within the window $(\sigma)$. A large difference in depth between the two methods was indicative of a broad thermocline. Total water column fluorescence was summed for the entire $500-\mathrm{m}$ cast and the depth of maximum fluorescence was calculated for each $20-\mathrm{m}$ lag window.

We used a universal kriging function in ARCGIS DESKTOP 9.2 (ESRI, 380 New York Street, Redlands, CA 92373-8100, USA) to interpolate and then divide the entire transect into $245625-\mathrm{km}^{2}$ grid cells to examine the effects of oceanography (thermocline and oxycline depth, total fluorescence and depth of maximum fluorescence, SST, SSH anomaly, ocean color, time of day, and latitude) on surface, midwater, deep water, and total water column backscatter. Generalized additive models (GAMs, s-plus 7.0, TIBCO, 212 Elm Street, Somerville, MA 02144, USA) were used to look for the non-linear effects of environmental variables on the backscattering cross-section $\left(\sigma_{\mathrm{bs}}=10^{20 / \mathrm{Sv}}\right)$ and to identify specific thresholds (Hastie and Tibshirani, 1990). To examine the environment near marine mammals, sighting coordinates were used to spatially sample the environmental and backscatter surfaces for qualitative analysis.

\section{RESULTS}

SSH anomaly was lowest at the equator $(-10 \mathrm{~cm})$ and southwest of the Hawaiian Islands $\left(-20 \mathrm{~cm}, 15^{\circ} \mathrm{N}\right.$; Fig. 1). Surface backscatter was also greatest at the equator, with the majority of observed backscatter between $6^{\circ} \mathrm{S}$ and $10^{\circ} \mathrm{N}$, including a cycle of greater backscatter during the day (Fig. 1, Table 1). The major geostrophic and wind-driven currents were

Figure 2. Acoustic Doppler Current Profiler results in zonal and meridional velocity $\left(\mathrm{cm} \mathrm{s}^{-1}\right)$ with latitude and depth. For zonal velocity, eastward flow is indicated in dark gray with westward flow, indicated in light gray for meridional velocity; northward flow is indicated in dark gray with southward flow in light gray.
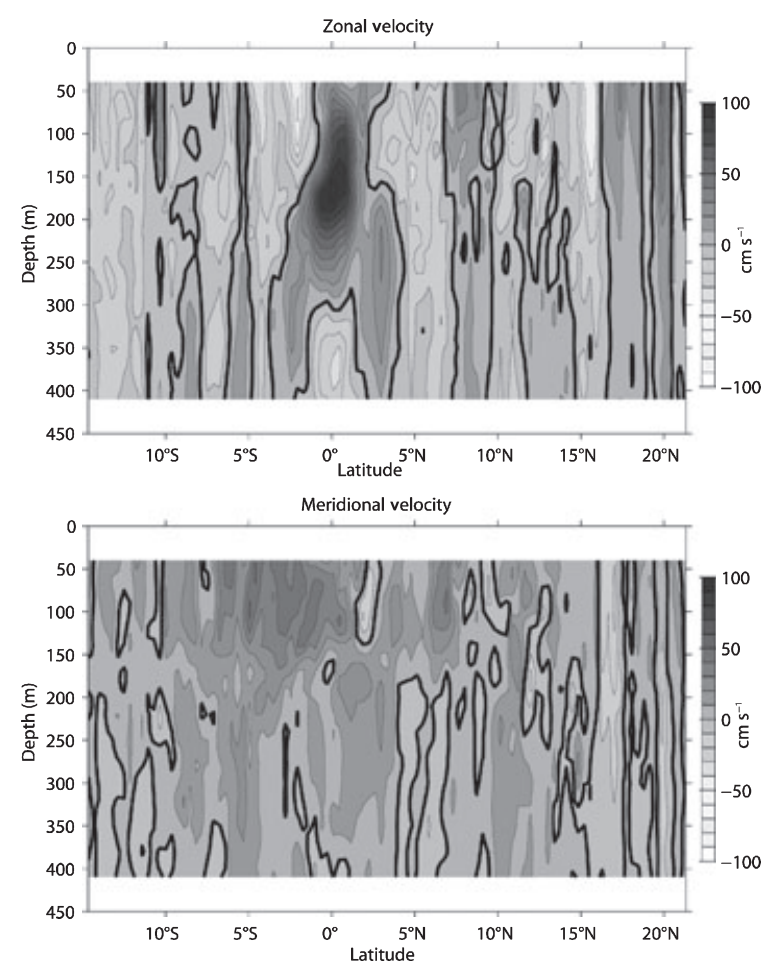
Figure 3. (a) Mean scattering volume $\left(\mathrm{dB} \mathrm{m}^{-3}\right)$ plot with depth and latitude. For analyses these data were binned into surface $(0-200 \mathrm{~m})$, midwater $(200-550 \mathrm{~m})$ and deep $(550-1000 \mathrm{~m})$. (b) Fluorescence $\left(\mathrm{mg} \mathrm{Chl}-\mathrm{a} \mathrm{m}{ }^{-3}\right)$ and $(\mathrm{c})$ temperature $\left({ }^{\circ} \mathrm{C}\right)$ plotted against latitude and depth for the entire cruise track.
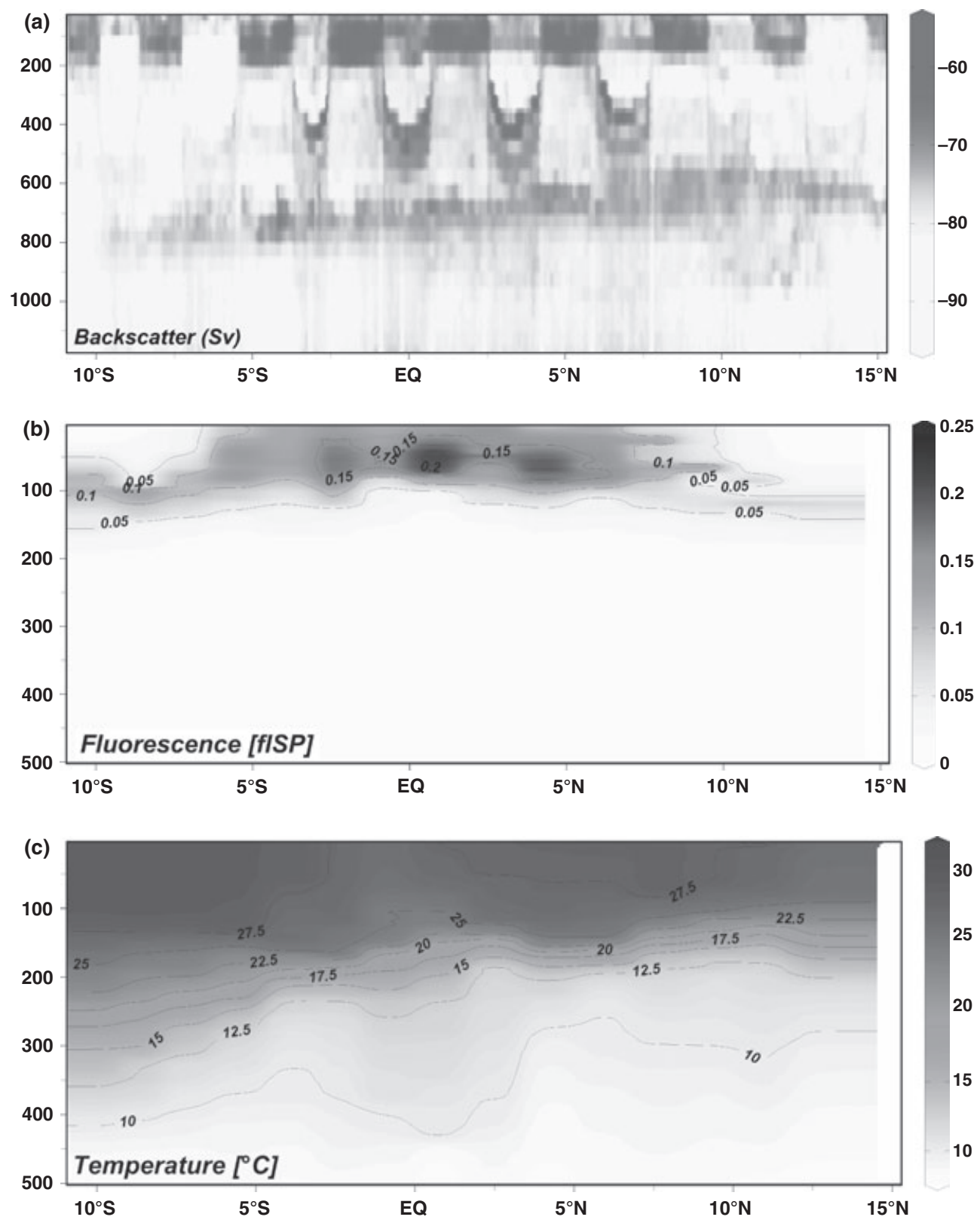

apparent on ADCP plots of zonal velocity with the EUC visible between 75 and $250 \mathrm{~m}$ in depth and current velocities $>100 \mathrm{~cm} \mathrm{~s}^{-1}$. Both arms of the SEC $\left(2^{\circ} \mathrm{S}\right.$ and $\left.5^{\circ} \mathrm{N}\right)$ and the NEC $\left(10-20^{\circ} \mathrm{N}\right)$ were visible flowing westward at the surface, with the SECC and NECC $\left(5^{\circ} \mathrm{S}\right.$ and $\left.6-9^{\circ} \mathrm{N}\right)$ flowing eastward (Fig. 2).

Throughout the entire cruise we observed a static DSL that ranged from 650 to $800 \mathrm{~m}$ in depth with a mean depth of $675 \mathrm{~m}$ (Fig. 3a). The static DSL shoaled with a northward change in latitude until $\sim 8^{\circ} \mathrm{N}$, where it remained constant at $650 \mathrm{~m}$. In contrast, the midwater DSL (300-600 m) exhibited a strong and predictable diel vertical migration (DVM) toward the surface $(0-200 \mathrm{~m})$ during night hours (Fig. 3a). Areas of highest chlorophyll-a occurred during the day immediately north of the equator, at $2^{\circ} \mathrm{S}$, and at $5^{\circ} \mathrm{N}$ with a mean depth of $50 \mathrm{~m}$ (Fig. 3b). The thermocline showed a similar trend as 
the static DSL shoaling from $275 \mathrm{~m}$ at $15^{\circ} \mathrm{S}$ to $175 \mathrm{~m}$ and remaining at a constant depth at latitudes $>8^{\circ} \mathrm{N}$ (Fig. 3c). The top $500 \mathrm{~m}$ of the water column was entirely normoxic south of the equator, although there was a strong hypoxic wedge from $500 \mathrm{~m}$ up to $200 \mathrm{~m}$ deep around $10^{\circ} \mathrm{N}$ (not shown). Salinity was highest $(>36)$ in a vertically compact wedge with mean depth of $175 \mathrm{~m}$ observed between $10^{\circ}$ and $3^{\circ} \mathrm{S}$.

Backscatter in the entire water column was related to latitude, thermocline depth $(\sigma)$, oxycline depth $(\sigma)$, total water column fluorescence, depth of maximum fluorescence, SST, and time of day (Table 1). Both mid- and deep backscatter values had significant relationships with the thermocline and oxycline depths $(\Delta)$ as well as with blended SST values. Surface chlorophyll-a from satellite imagery was only significant for backscatter at mid depths while SSH anomaly and deviance were significantly correlated with backscatter at mid values.

There were a total of 44 marine mammal sightings throughout the entire transect, consisting of six sightings of false killer whales (Pseudorca crassidens), five pilot whale sightings (Globicephala macrorhynchus), two sperm whale sightings (Physeter macrocephalus), four spinner dolphin sightings (Stenella longirostris), one Pacific spotted dolphin sighting (Stenella attenuata), 17 unidentified dolphin sightings, two minke whale sightings (Balaenoptera acutorostrata), and one killer whale sighting (Orcinus orca). Small odontocete sightings were grouped into three 'guilds' (pilot whales, stennellids, false killer whales) for qualitative analysis of oceanographic and prey conditions. Although stennelid species have varied diets, the number of unidentified stenellids during our survey makes it impossible to perform species-specific analyses. Pilot whale sightings occurred at higher SSTs, higher deep and midwater backscatter values (200$1000 \mathrm{~m}$ ), and lower SSH anomaly values compared to false killer whales (Fig. 4).

\section{DISCUSSION}

This study reveals a correlation between low SSHA values at the equator with increased chlorophyll- $a$ and DSL scattering intensity. In addition to time of day influencing diel vertical migration, the depth of maximum fluorescence was correlated with increased DSL scattering intensity in the surface, midwater, and deep scattering layers. Although there was a general trend of backscatter increasing with a deeper thermocline, a narrower oxycline was also correlated with higher DSL scattering intensity. In addition, both the
Figure 4. Sampled physical and biological parameters nearest to marine mammal sightings subtracting the mean transect values at the mesoscale $(25 \times 25 \mathrm{~km})$. (a) Pilot whales were seen in areas of greater mid $(200-550 \mathrm{~m})$ and deep $(550-1000 \mathrm{~m})$ backscatter compared to the other two guilds. The trend was reversed for surface waters $(>200 \mathrm{~m})$, with stelennid sightings having the greatest backscatter measurements. (b) SST was highest with SSH anomaly lowest (yet positive) at pilot whale sightings. False killer whales were sighted at the highest SSH anomaly values. (c) Pilot whales were sighted at the greatest concentrations of chlorophyll- $a$ and total water column fluorescence measurements with false killer whale sightings having the least.

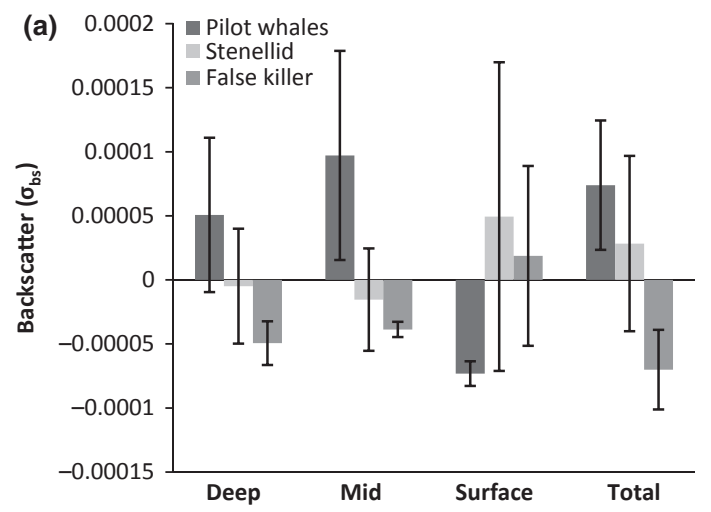

(b)
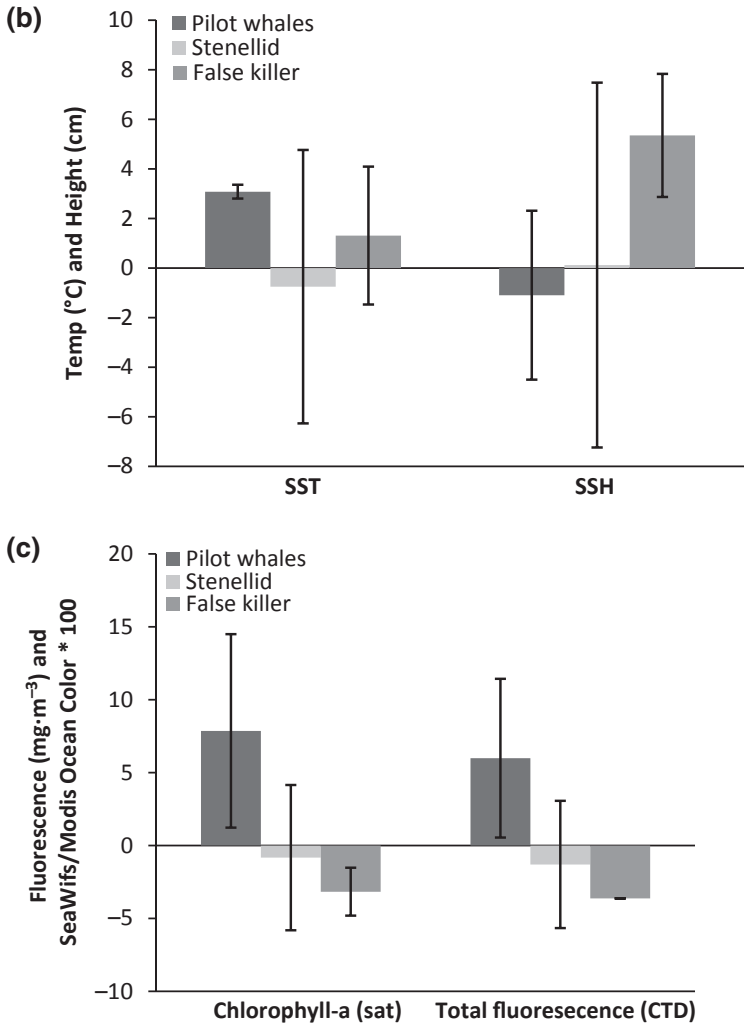
surface and deep scattering layers were significantly correlated with depth of the oxycline and thermocline, suggesting the migratory layer settles above the thermocline during the night and below the thermocline during the day.

Previous research has observed a shallowing of the thermocline from south to north in the central equatorial Pacific (Wyrtki and Kilonsky, 1984; Johnson et al., 2002), and notably we found a similar pattern in DSL mean depth. The southward migration of the ITCZ, wind stress, and consequent Ekman pumping leads to a pattern of northward shoaling of the thermocline (Wang et al., 1999; Kessler, 2006). DSL depth has been shown to be a function primarily of irradiance (Frank and Widder, 2002) and secondarily of temperature (Tont, 1976; Frank and Widder, 2002) and both factors may influence the shoaling of the DSL in this system. The increased scattering intensity at the surface during the daytime at the equator and at $4^{\circ} \mathrm{N}$ suggests an additional non-migratory layer is present in these areas of low SSH anomaly and high chlorophyll-a (Fig. 3a).

The correlation of sighting data by 'guild' to oceanographic and biological measurements supports known foraging patterns. Pilot whales that feed on deep squid (Sinclair, 1992; Pauly et al., 1998; Soto et al., 2008) were sighted in areas with higher midand deep backscatter. False killer whales and stenellid dolphins, which tend to forage on prey in near-surface waters (Perrin et al. 1973, Pauly et al., 1998; Baird et al., 2008), were sighted in areas of greater shallow backscatter, greater SSH anomaly values, and had no discernible relationship with chlorophyll-a.

Our examination of the deep scattering layer relative to oceanographic features and potential cetacean predators at $160-174^{\circ} \mathrm{W}$ resulted in a number of novel findings. The depth of the DSL shoals toward the surface from $800 \mathrm{~m}$ at $5^{\circ} \mathrm{S}$ to $650 \mathrm{~m}$ at $10^{\circ} \mathrm{N}$ (Fig. 3a), which parallels the shoaling of the thermocline from $250 \mathrm{~m}$ at $10^{\circ} \mathrm{S}$ to $180 \mathrm{~m}$ at $10^{\circ} \mathrm{N}$ (Fig. 3c). Backscatter was greater at the surface during daytime hours near the equator, suggesting a change in species composition at the equator or possibly that foraging potential was greater than predation risk for migrating organisms at these latitudes. Spatial trends in DSL patterns were largely influenced by diel effects, but fluorescence (depth and strength) still had a significant relationship with pelagic scatterers in all portions of the water column across the transect (Table 1). With DSL organisms serving as a critical forage base in the tropical Pacific, additional research is needed to understand variation in distribution and abundance of DSL organisms. This study illustrates that determining the factors that influence DSL distribution is a valuable step towards understanding the relationship of physical oceanography and top predators in pelagic environments.

\section{ACKNOWLEDGEMENTS}

We would like to thank the crew and scientific party (Lisa Conger, Siri Hakala, Tamara Maguire, Hugh Finn, and Shannon Rankin) and crew aboard the NOAA vessel O.E. Sette for their aid in data collection and cruise operations. Jaime Gove aided in ADCP analysis. Dr. Reka Domokos, Dr. Jeffrey Polovina, Dr. Dick Barber, Dr. Douglas Nowacek, Jason Roberts and particularly Dave Foley provided helpful comments, edits on the manuscript, and assistance with oceanographic products. These data were collected under US MMPA/ESA permit 774-1714-03.

\section{REFERENCES}

Baird, R.W., Gorgone, A.M., McSweeney, D.J. et al. (2008) False killer whales (Pseudorca crassidens) around the main Hawaiian Islands: long-term site fidelity, inter-island movements, and association patterns. Mar Mamm Sci. 24:591612.

Ballance, L.T., Pitman, R.L. and Fiedler, P.C. (2006) Oceanographic influences on seabirds and cetaceans of the eastern tropical Pacific: a review. Prog. Oceanogr. 69:360-390.

Barham, E.G. (1948) Siphonophores and the deep scattering layer. Science 140:826-828.

Benoit-Bird, K.J. and Au, W.W.L. (2003) Prey dynamics affect foraging by a pelagic predator (Stenella longirostris) over a range of spatial and temporal scales. Behav. Ecol. Sociobiol. 53:364-373.

Bertrand, A., Bard, F.X. and Josse, E. (2002) Tuna food habits related to the micronekton distribution in French Polynesia. Mar. Biol. 140:1023-1037.

Buckland, S.T. and Elston, D.A. (1993) Empirical models for the spatial distribution of wildlife. J. App. Ecol. 30:478-495.

Clarke, T. (1973) Some aspects of the ecology of lanternfishes in the Pacific Ocean near Hawaii. Fish. Bull. 71:401-434.

Dagorn, L., Bach, P. and Josse, E. (2000) Movement patterns of large bigeye tuna (Thunnus obesus) in the open ocean, determined using ultrasonic telemetry. Mar. Biol. 136:361371.

Domokos, R., Seki, M.P., Polovina, J.J. and Hawn, D.R. (2007) Oceanographic investigation of the American Samoa albacore (Thunnus alalunga) habitat and longline fishing grounds. Fish. Oceanogr. 16:555-572.

Firing, E., Ranada, J. and Caldwell, P. (1995) Processing ADCP Data with the CODAS Software System, Version 3.1. Honolulu, HI: University of Hawaii, pp. 226.

Frank, T.M. and Widder, E.A. (2002) Effects of a decrease in downwelling irradiance on the daytime vertical distribution patterns of zooplankton and micronekton. Mar. Biol. 140:1181-1193.

Gliwicz, Z.M. (1986) Predation and the evolution of vertical migration in zooplankton. Nature 320:746-748. 
Hastie, T. and Tibshirani, R. (1990) Generalized Additive Models. New York: Chapman \& Hall, pp. 41.

Jaquet, N. and Whitehead, H. (1996) Scale-dependent correlation of sperm whale distribution with environmental features and productivity in the South Pacific. Mar. Ecol. Prog. Ser. 135:1-9.

Johnson, G.C., Sloyan, B.M., Kessler, W.S. and McTaggart, K.E. (2002) Direct measurements of upper ocean currents and water properties across the tropical Pacific during the 1990s. Prog. Oceanogr. 52:31-61.

Kessler, W.S. (2006) The circulation of the eastern tropical Pacific: a review. Prog. Oceanogr. 69:181-217.

Longhurst, A.R. (2006) Ecological Geography of the Sea. New York: Academic Press, pp. 497.

Pauly, D., Trites, A.W., Capuli, E. and Christensen, V. (1998) Diet composition and trophic levels of marine mammals. ICES J. Mar. Sci. 55:467-481.

Perrin, W.F., Warner, R.R., Fiscus, C.H. and Holts, D.B. (1973) Stomach contents of porpoise, Stenella spp., and yellowfin tuna, Thunnus albacares, in mixed-species aggregations. Fish. Bull. 71:1077-1092.
Powell, B.S., Arango, H.G., Moore, A.M., Di Lorenzo, E., Milliff, R.F. and Foley, D. (2008) 4DVAR data assimilation in the intra-Americas sea with the Regional Ocean Modeling System (ROMS). Ocean Modelling 23:130-145.

Roger, C. and Grandperrin, R. (1976) Pelagic food webs in the tropical Pacific. Limnol. Oceanogr. 21:731-735.

Sinclair, E.H. (1992) Stomach contents of short-finned pilot whales (Globicephala macrorhynchus) from the southern California bight. Mar. Mamm. Sci. 8:76-81.

Soto, N.A., Johnson, M.P., Madsen, P.T. et al. (2008) Cheetahs of the deep sea: deep foraging sprints in short-finned pilot whales off Tenerife. J. Anim. Ecol. 77:936-947.

Tont, S.A. (1976) Deep scattering layers: patterns in the pacific. CalCOFI Rep., 18:112-117.

Wang, B., Wi, R. and Lukas, R. (1999) Annual adjustment of the thermocline in the tropical Pacific ocean. J. Climate 13:596-616.

Wyrtki, K. and Kilonsky, B. (1984) Mean water and current structure during the Hawaii to Tahiti shuttle experiment. J. Phys. Oceanogr. 14:242-254. 